\title{
The Energetics of Encephalization in Early Hominids
}

\author{
J. Josh Snodgrass \\ Department of Anthropology, University of Oregon \\ 1218 University of Oregon, Eugene, OR 97403 USA \\ jjosh@uoregon.edu \\ William R. Leonard \\ Department of Anthropology, Northwestern University, \\ 1810 Hinman Ave., Evanston, IL 60208 USA \\ Marcia L. Robertson \\ Department of Anthropology, Northwestern University \\ 1810 Hinman Ave., Evanston, IL 60208 USA
}

\begin{abstract}
Bioenergetics, the study of the use and transfer of energy, can provide important insights into the ecology and evolution of early hominids. Despite a relatively large brain with high metabolic demands, contemporary humans and other primates have resting metabolic rates (RMRs) that are similar to those of other mammals. As a result, a comparatively large proportion of their resting energy budget is spent on brain metabolism among humans ( 20-25\%) and other primates ( $\sim 8-10 \%)$ compared to other mammals ( 3-5\%). To understand this shift in energy budget, Aiello and Wheeler's Expensive Tissue Hypothesis (ETH) posits a metabolic trade-off-a reduction in gut size with brain size increase - to explain this phenomenon. Here, we explore the interrelationships between brain size, body size, diet, and body composition using comparative data for humans, non-human primates, and other mammals. Among living primates, the relative proportion of energy allocated to brain metabolism is positively correlated with dietary quality. Contemporary humans fall at the positive end of this relationship, having both a high quality diet and a large brain. Thus, high costs associated with the large human brain are supported, in part, by energy-rich diets. Although contemporary humans display relatively small guts, primates as a group have gut sizes that are similar to non-primate mammals. In contrast, humans and other primates have significantly less skeletal muscle for their size compared to other mammals. These comparative analyses suggest that alterations in diet quality and body composition were necessary conditions for overcoming the constraints on encephalization. Fossil evidence indicates that brain expansion with the emergence of Homo erectus at about 1.8 million years ago was likely associated with important changes in diet, body composition, and body size.
\end{abstract}

Keywords: bioenergetics; ecology; hominid evolution; dietary quality; body composition; scaling

Running head: Energetics of Encephalization 


\section{Introduction}

Bioenergetics, the study of the use and transfer of energy, can provide important insights into the ecology and evolution of early hominids. Energy dynamics represent a central interface between an organism and its environment; how energy is extracted from limited environmental resources and allocated to various somatic functions has consequences in terms of survival and reproduction (McNab, 2002; Leonard and Ulijaszek, 2002; Leonard et al., 2007). Thus, energy provides a useful currency for measuring fitness. Energy dynamics also shape aspects of an organism's life history, given that energy used for functions related to maintenance (e.g., resting metabolic rate [RMR], physical activity, and thermoregulation) cannot be used for production, such as the metabolic costs associated with growth and reproduction.

Energetic studies offer a window into hominid brain evolution, as an increase in the size of this metabolically expensive organ requires a shift in energy allocation-either an absolute increase in energy intake or a reduction in the portion of energy allotted to other components of energy expenditure. Consequently, encephalization may affect an organism's life history pattern and shape variables such as the timing of weaning, age at maturity, and reproductive scheduling (Bogin, 1999, 2002). Non-human primates, including hominids, are distinct from most other mammals in having relatively large brains for their body size, a pattern noted by numerous authors (e.g., Martin, 1990). Modern humans have extended this trend and, with brains averaging approximately $1300 \mathrm{~g}$, are outside the range of other living primates (Jerison, 1973; Leonard and Robertson, 1992).

The metabolic cost of brain tissue is approximately $240 \mathrm{kcal} / \mathrm{kg} /$ day and as such is considerably higher than certain tissues such as skeletal muscle (13 kcal/kg/day, at rest), similar to other organs such as the liver ( $200 \mathrm{kcal} / \mathrm{kg} / \mathrm{day})$, and lower than others such as the heart (440 kcal/kg/day) (Holliday, 1986; Elia, 1992). Given that humans and other primates 
(including great apes) have RMRs similar to other mammals (Leonard and Robertson, 1992, 1994; Aiello and Wheeler, 1995; Snodgrass et al., 2007), despite their relatively large brains, a comparatively large proportion of the resting energy budget is expended on brain metabolism in living humans (20-25\%) and non-human primates (8-10\%) compared to other mammals (3-5\%) (Leonard and Robertson, 1994; Aiello and Wheeler, 1995).

While many studies of primate brain evolution have concentrated on identifying the causal selective factors associated with encephalization in non-human primates and hominids, other studies have taken a different approach and considered the factors associated with the ability to grow and maintain large brains in these taxa (e.g., Leonard and Robertson, 1994; Aiello and Wheeler, 1995; Leonard et al., 2003). These latter studies have concentrated on elucidating the ways that non-human primates and hominids, in particular, overcame the energetic constraints on encephalization. Following a similar approach, in the present chapter we use comparative data on living mammals (including humans and other primates) coupled with information on fossil hominids to consider the energetics of brain evolution as related to diet, body composition, and body size. We use these comparative data to test several hypotheses. First, we hypothesize that among non-human primates dietary quality (i.e., the energy and nutrient density of the diet) will be inversely related to body mass, as predicted by the Jarman-Bell relationship (Bell, 1971; Jarman, 1974). Second, we predict among nonhuman primates relative brain size and relative diet quality will be positively associated (i.e., species with relatively large brains will consume relatively high quality diets. Third, we hypothesize that non-human primates will have smaller gut sizes than non-primate mammals, as predicted by the Expensive Tissue Hypothesis (Aiello and Wheeler, 1995). Finally, we predict that non-human primates will have less total skeletal muscle mass compared to nonprimate mammals. 


\section{Materials and Methods}

We compiled data from published sources on RMR, diet, and body size for living humans and non-human primates (Table 1). Only adult animals were included, and for each species we calculated a single unweighted combined-sex average for each variable. Additionally, we compiled brain size and body mass estimations for fossil hominid species (Table 2).

Resting metabolic rate and body mass $(\mathrm{kg})$ data were obtained for 41 primate species, including humans (Table 1). All RMR values are expressed as kilocalories per day (kcal/day) and were converted from other units if necessary. RMR, which is the amount of energy used by an inactive animal under thermoneutral conditions, is only one component of the total energy expenditure (TEE) of an animal and thus does not provide a complete picture of energy dynamics. Unfortunately, only minimal data on other energetic parameters (e.g., physical activity, thermoregulation, and the thermic effect of food) are presently available for free-living non-human primates; this severely limits the ability to perform comparative analyses.

We used the dietary quality (DQ) index of Sailer and colleagues (1985) to estimate the energy and nutrient density of the diet for a variety of primate species. The DQ index is a weighted average of the proportions of plant structural parts ( $s$; leaves, stems, and bark), reproductive parts ( $r$; fruits, flowers, and nectar), and animal matter ( $a$; vertebrates and invertebrates) and is calculated as:

$$
\mathrm{DQ}=s+2 r+3.5 a
$$

DQ ranges from a minimum of 100 (100\% foliage) to 350 (100\% animal material). DQ values were available for 32 species of non-human primate (Table 1). The diversity of human diets, past and present, prevents calculation of an all-inclusive DQ. However, to get a general picture of human diet, we used the average DQ of five contemporary forager groups based on data compiled by Leonard and Robertson (1994). 
Body composition data considered in the present study include measures of the mass of the gastrointestinal (GI) tract, skeletal muscle, and body fat. To examine the relationship between GI mass $(\mathrm{g})$ and body mass $(\mathrm{kg})$ in primates and other mammals, we compiled published data (Pitts and Bullard, 1968; Tipton and Cook, 1969; Chivers and Hladik, 1980); typesetting errors in the Chivers and Hladik (1980) paper were corrected (Chivers, personal communication). Total GI mass represents the combined mass of the stomach, small intestine, cecum, and colon. Data were available for 23 species of primates (including humans) and 56 species of non-primate mammals.

Information on skeletal muscle mass $(\mathrm{g})$ and body mass $(\mathrm{kg})$ was compiled from published sources (Wang et al., 2001; Muchlinski et al., 2003, in prep.). Data were available for 22 species of primates (including humans) and 56 species of non-primate mammals. We examined the relationship of muscularity to locomotor behavior by classifying each species (excluding humans and bats) as arboreal or terrestrial according to primary locomotor habit; while this dichotomy is overly simplistic, it is used simply to get a general picture of habitat use.

Allometric relationships were determined using ordinary least squares regressions of $\log _{10}$-transformed data. Pearson's correlations were used to assess the relationship between DQ and body mass, as well as between relative DQ and relative brain mass. Human data were excluded from the calculation of correlations and regression parameters, unless indicated. Differences between primate and non-primate mammalian regression parameters were assessed using Student's t-tests. One-Way ANOVA (Scheffe's post-hoc test) was used to assess differences between terrestrial and arboreal primates and non-primate mammals. All analyses were performed using SPSS 12.0 (Chicago, IL). 


\section{Results}

The scaling relationship of RMR and body mass among primates (including humans) is RMR $=54.7$ Mass $^{0.81}\left(r^{2}=0.94\right)$. This is similar to the relationship seen across mammals (i.e., the Kleiber scaling relationship): $\mathrm{RMR}=70 \mathrm{Mass}^{0.75}$. Humans fall almost exactly on the primate regression line $($ standardized residual $=0.08)$.

Dietary quality shows a significant inverse correlation with body mass among primates, with humans excluded $(n=32)\left(P<0.001 ; r^{2}=0.46\right)$. We used a DQ value for humans of 263, which is an average of five human foraging populations (!Kung [235.5], Ache [263.0], Hiwi [287.0], Ituri Pygmies [252.5], and Inuit [343.4]). The human DQ value was substantially higher than expected for body size, falling outside the $95 \%$ confidence intervals for a regression of DQ versus body mass for all primates (humans included). Despite considerable dietary differences between contemporary forager groups, including differences in percent of energy derived from animal material (e.g., 33\% in !Kung vs. 96\% in the Inuit), the diets of all five groups fall substantially above the primate regression line.

We considered the relationship between relative brain size and relative DQ among living primate species, including humans $(n=31)$. There is a strong positive association between the amount of energy allocated to the brain and the caloric and nutrient density of the diet $\left(\mathrm{P}<0.001 ; \mathrm{r}^{2}=0.41\right)$. Humans fall outside the $95 \%$ confidence interval for a regression of relative brain size versus relative DQ; humans are extreme outliers for both relative DQ and relative brain size.

The scaling coefficient between gastrointestinal tract mass and body mass is comparable between the primate (humans excluded) and mammalian samples $(0.99 \pm 0.05 \mathrm{vs}$. $0.98 \pm 0.02 ;$ n.s.) (Figure 1). The primate regression has a slightly higher y-intercept than that of non-primate mammals, although this relationship is not significantly different (y- 
intercept $=1.66 \pm 0.04$ vs. $1.63 \pm 0.02 ;$ n.s. $).$ Humans are outside the $95 \%$ confidence intervals from a regression of primates and other mammals.

When the scaling relationship of skeletal muscle mass versus body mass is compared between primates and other mammals, primates have significantly lower muscle masses for their body size. Primates have a significantly lower y-intercept than non-primate mammals $(2.53 \pm 0.02$ vs. $2.65 \pm 0.01 ; \mathrm{P}<0.001)$, although the scaling coefficients are significantly different $(1.05 \pm 0.02$ in primates and $0.99 \pm 0.01$ in non-primate mammals; $\mathrm{P}<0.05)$. Mean $\mathrm{z}$-scores are significantly lower in primates $(\mathrm{z}=-0.71 \pm 0.22$ in primates vs. $0.27 \pm 0.11$ in non-primate mammals; $\mathrm{P}<0.001)$. The differences in muscularity between arboreal $(\mathrm{n}=23)$ and terrestrial $(n=45)$ species are evident from the $\mathrm{z}$-scores from the skeletal muscle mass versus body weight regression for all species. For all mammals (including primates), arboreal species are significantly less muscular than terrestrial species $(z=-0.87 \pm 0.23$ vs. $0.44 \pm 0.08 ; \mathrm{P}<0.001)$. Terrestrial mammals are the most well-muscled group $(\mathrm{z}=0.53 \pm$ $0.09)$, having a significantly greater residual score than arboreal mammals $(z=-0.70 \pm 0.45$; $\mathrm{P}<0.001)$ and arboreal primates $(\mathrm{z}=-0.98 \pm 0.25 ; \mathrm{P}<0.001)$. Terrestrial primates $(\mathrm{z}=-0.02$ $\pm 0.18)$ have significantly higher $\mathrm{z}$-scores than arboreal primates $(\mathrm{P}<0.05)$. Terrestrial mammals are not significantly different than terrestrial primates $(\mathrm{P}=0.31)$. Humans fall slightly below (standardized residual $=-0.65$ ), although there are substantial differences between males and females (Figure 2).

\section{Discussion}

\section{Diet Quality}

The relationship of resting metabolism and body mass in mammals is negatively allometric, as RMR scales to the three-quarters power of body mass (Kleiber, 1961). The energetic consequence of this scaling relationship is that small mammals have low total energy needs 
but high mass-specific energy demands. Conversely, large mammals have high total energy needs but low mass specific costs. These metabolic patterns constrain diet and foraging strategies (Bell, 1971; Jarman, 1974; Gaulin, 1979; Leonard and Robertson, 1994; see also Kay, 1984). Small-bodied mammals must consume foods with high caloric and nutritive values (e.g., insects, saps, and gums), which tend to be distributed in patches, while largebodied mammals typically exploit low quality food items that are nutrient and energy poor and hard to digest (e.g., leaves and bark) but tend to be ubiquitous in the environment.

Results from the present study support the hypothesis that diet quality is inversely related to body mass among primates, and is consistent with results from several earlier studies (Sailer et al., 1985; Leonard and Robertson, 1994). Large-bodied primates (e.g., Pongo pygmaeus) generally consume fairly low quality diets that often include leaves, fruit, bark, and shoots, and limited quantities of animal foods, while small primates (e.g., strepsirhines and certain haplorhines), consume higher quality diets that include a considerable amount of animal prey (especially invertebrates) and high quality plant foods.

In contrast to the pattern seen in non-human primates and other mammals, contemporary humans have a diet that is significantly higher in quality than expected for body size. The high quality diet results from the inclusion of energy-dense vegetable foods (e.g., nuts and fruits) and, more importantly, the consumption of large quantities of animal (especially vertebrate) foods. Although contemporary humans have an enormous dietary diversity (even if only foragers are considered), all five foraging populations considered here lie well above the primate regression. Despite variation in the amount and type of foods they eat, most contemporary human foraging populations consume over $50 \%$ of their calories from animal sources (Cordain et al., 2000; Kaplan et al., 2000); however, the contribution of hunted foods is influenced by latitude in contemporary foraging populations (Marlowe, 2005). In contrast, fewer than $15 \%$ of forager groups obtain more than half their diet from 
plant foods. The high quality plant and animal foods attractive to human foragers are, in general, more patchily distributed and require more skills to acquire (i.e., through extraction or hunting) than the collected foods that comprise nearly the entire great ape diet (Kaplan et al., 2000). Thus, technology (i.e., tools) and transmission of learned skills and information are particularly important for successful acquisition of these dietary resources.

The inclusion of substantial quantities of animal foods in the human diet contrasts markedly with most other primates who largely rely on plant foods; certain small-bodied species, however, consume large quantities of invertebrates (e.g., insects). Great apes obtain nearly all their calories from plant foods and even the most carnivorous species, the common chimpanzee (Pan troglodytes), consumes only 2 to $13 \%$ of its calories from vertebrate foods (Stanford, 1996; Milton, 2003). Field studies indicate that meat is a highly desirable food item for many primate species; modest consumption reflects the limited ability of chimpanzees and other primates to obtain large and consistent quantities of vertebrate foods because of high acquisition costs (Milton, 1999).

In order to test our second hypothesis, which predicts that species with relatively large brains will consume higher quality diets, we examined the relationship between deviations from relative brain size and relative DQ among primates. Consistent with this hypothesis and with our earlier results using a smaller dataset (Leonard and Robertson, 1994) and findings from a recent study (Fish and Lockwood, 2003), we documented a strong positive association between energy allocated to the brain and the caloric and nutrient density of the diet.

Therefore, primate species with relatively large brains rely on energy-dense diets to support the high metabolic costs of the brain.

Humans represent an extreme example of this relationship, having the largest brains in the sample and the highest relative DQ. The consumption of an energy-dense and nutrientrich diet partially offsets the large, metabolically expensive brain, as has been suggested in 
other studies (Leonard and Robertson, 1994; Aiello and Wheeler, 1995). These empirical findings support Milton's (2003) hypothesis that increased consumption of meat and energydense plant foods (e.g., fruit) was necessary for humans to overcome the metabolic constraints on brain expansion. These findings do not imply that dietary change was the impetus for brain expansion among hominids; instead, consumption of a high quality diet was likely a prerequisite for the evolution of a large, energetically expensive brain in hominids. The consumption of nutritionally dense animal foods would have been especially important during early ontogeny, when infants and young children have extremely high metabolic demands from their relatively large energy-expensive brains yet possess immature digestive morphology and physiology (Kuzawa, 1998; Leonard et al., 2003).

Contemporary humans consume a high quality diet, but to understand the energetics of human brain evolution we must consider the timing of dietary change among earlier hominids. Various lines of evidence (e.g., comparative primate studies, stable isotopes, dental microwear, etc.) suggest that australopithecines consumed a varied and opportunistic diet that was largely composed of plant foods, such as fruits, seeds, and leaves, and included an assortment of $\mathrm{C}_{4}$ foods (e.g., grasses, sedges, and termites) (Teaford and Ungar, 2000; Sponheimer et al., 2005). Important dietary differences almost certainly existed between species, with certain later australopithecines (e.g., Australopithecus africanus) apparently expanding their dietary flexibility and breadth, and robust australopithecines (e.g., A. robustus) likely specializing on hard-object feeding. The consumption by australopithecines of limited quantities of animal foods (including invertebrates) is suggested by analogies with living primates (especially P. troglodytes), and supported by stable isotope studies and association with putative bone tools likely used for termite extraction (e.g., Backwell and d'Errico, 2001). 
Most authorities interpret paleontological and archaeological evidence as suggesting modest dietary change in earliest Homo (i.e., H. habilis); this species likely incorporated more animal foods in its diet, although the relative amounts obtained through hunting compared to scavenging are debated (Blumenschine, 1987; Harris and Capaldo, 1993; Plummer, 2004). Evidence for dietary change in this species can be seen in the reduced masticatory functional complex (e.g., posterior tooth size); dental reduction in H. habilis reversed successive increases in cheek tooth size among the australopithecines (McHenry and Coffing, 2000). Technological advancements, such as the development of Oldowan Industry tools, would likely have allowed easier processing of vertebrate carcasses and increased access to meat, as well as energy and nutrient rich marrow and brains (Semaw et al., 2003; Plummer, 2004).

Multiple lines of evidence suggest a significant dietary shift with the evolution of $H$. erectus; this appears as part of an adaptive shift in this species, which included changes in brain and body size, limb proportions, and various aspects of behavior (Wood and Collard, 1999; Aiello and Key, 2002). However, recent work by Antón (2008) suggests that this foraging shift may have taken place earlier (i.e., with $H$. habilis), and that a smaller dietary shift occurred with the transition to H. erectus. Fossil evidence suggests that the period beginning approximately 2 million years ago (Ma), with the evolution of $H$. habilis and $H$. erectus, saw the first sizeable increases in brain volume in hominids (Table 2). While earlier hominid species showed brain sizes averaging $530 \mathrm{~cm}^{3}$ or less, brain size increased in $H$. habilis (sensu strictu; averaging approximately $610 \mathrm{~cm}^{3}$ ) and early Homo erectus (averaging approximately $860 \mathrm{~cm}^{3}$ ). Although brain size in H. erectus is smaller than that of modern humans, it is outside the range seen in non-human primates. However, body size increased too and the enlarged brain size in $H$. erectus may not have represented a grade shift. Further, recent fossil finds attributed by many researchers to $H$. erectus, such as from Ileret (Spoor et 
al., 2007) and Dmanisi (Lordkipanidze et al., 2007), document fairly small body size in at least some members of the species; this has complicated the picture of this species and has raised questions about the extent of geographic variation and the degree of sexual dimorphism (e.g., Antón et al., 2007).

The adaptive shift seen in $H$. erectus, including dietary change, may have been precipitated by environmental changes in eastern and southern Africa. The first appearance of H. erectus at 1.8 Ma (in East Africa; Antón 2003) is coincident with a punctuated event within the context of a long-term global-scale environmental shift that began in the late Pliocene; this environmental change was characterized by stair step increases in aridity in eastern Africa (deMenocal, 1995, 2004; Bobe and Behrensmeyer, 2002; Wynn, 2004). This climatic shift appears to have heightened climatic variability and led to an overall increase in ecosystem heterogeneity; as a result, this period saw a decrease in forested area and an expansion of open woodlands and grasslands (Hopley et al., 2007). Given this climatic change, the type and distribution of food available to hominids would likely have radically shifted during this period (Behrensmeyer et al., 1997; Plummer, 2004). According to modern savanna ecosystems estimates, primary productivity in early Pleistocene Africa was substantially lower than in the Pliocene, thus limiting the edible plant foods available to hominids (see Leonard and Robertson, 1997, 2000). However, secondary (herbivore) and tertiary (carnivore) trophic-level foods likely increased in abundance; this ecological shift would have increased the overall mammalian biomass, especially of ungulates and other large mammals, available to hominids with the technological and cognitive abilities necessary to exploit this resource (Leonard et al., 2003). In fact, behavioral flexibility within the context of environmental variability and ecosystem heterogeneity may have served as an important selective factor in hominid encephalization (Potts, 1998). 
Evidence from archaeological sites has been interpreted by several authorities to suggest a dietary shift in H. erectus - specifically, the incorporation of more hunted foods in the diet. H. erectus probably occupied a higher predatory position than earlier hominids given evidence for early access to mammalian carcasses through hunting and confrontational scavenging (Plummer, 2004). Increasingly sophisticated stone tools (i.e., the Acheulean Industry), which emerged around 1.6-1.4 Ma, almost certainly improved the ability of hominids to process animal and plant materials (Asfaw et al., 1992). Also evident is an increased behavioral complexity that appears to have included food sharing, changes in landuse patterns, and the emergence of a rudimentary hunting and gathering lifeway (Harris and Capaldo, 1993; Rogers et al., 1994).

Dietary change in $H$. erectus has also been inferred from morphological evidence. The reduced size of the posterior teeth and gracility of certain aspects of craniofacial and mandibular morphology are consistent with a diet with less fiber, fewer hard food items, and an overall reduction in the emphasis on mastication (McHenry and Coffing, 2000).

An alternative strategy for increasing dietary quality in early Homo was proposed by Wrangham and colleagues (1999; Wrangham and Conklin-Brittain, 2003; Wrangham, 2007) and focuses on the use of cooking to improve the nutritional density of certain foods. They note that the cooking of savanna tubers and other plant foods would have served to both soften them and increase their energy and nutrient content. In their raw form, the starch in roots and tubers is not absorbed in the small intestine and instead is passed through the body as non-digestible carbohydrate (Tagliabue et al., 1995; Englyst and Englyst, 2005).

However, when heated, the starch granules swell and are disrupted from the cell walls, making the starch more accessible to digestive breakdown and increasing the carbohydrate energy available for biological purposes (García-Alonso and Goñi, 2000). Although cooking is clearly an important innovation in hominid evolution that served to increase dietary 
digestibility and quality, there is very limited evidence for the controlled use of fire by hominids prior to 1.5 Ma (Brain and Sillen, 1988; Bellomo, 1994; Pesini, 1999). The more widely held view is that the use of fire and cooking did not occur until considerably later in human evolution, probably closer to 200-250,000 years ago (Straus, 1989; Weiner et al., 1998), although possibly as early as 400,000 years ago (Preece et al., 2006). In addition, nutritional analyses of wild tubers used by modern foragers (e.g., Schoeninger et al., 2001) suggest that the energy content of these resources is markedly lower than that of animal foods, even after cooking (Cordain et al., 2001). This, however, does not preclude the possibility that tubers and other plant underground storage organs (USOs) were an important food resource for $H$. erectus and for other hominid species, especially as a fallback food (Hatley and Kappelman, 1980; Wrangham et al., 1999; Laden and Wrangham, 2005).

In addition to requiring an energy-dense diet, the human brain has additional demands for essential fatty acids (e.g., long-chain polyunsaturated fatty acids, such as arachidonic acid [AA] and docosahexanoic acid [DHA]) that are critical for optimal neural development and functioning (Fernstrom and Fernstrom, 2003). As reviewed by Cordain and colleagues (2001), evolutionary increases in mammalian brain size are apparently constrained by the limited dietary availability in plants of certain fatty acids (i.e., linoleic acid and $\alpha$-linolenic acid) that are necessary for conversion to AA and DHA. Certain carnivorous species, however, circumvent constraints on endogenous synthesis by directly ingesting AA and DHA in prey species. Limitations in the availability of AA and DHA could have been a barrier to encephalization in australopithecines if they consumed only limited quantities of vertebrate foods. However, early members of the genus Homo would have markedly increased their consumption of AA and DHA by direct consumption of these fatty acids in the tissues (e.g., brain, muscle, fat, and liver) of terrestrial mammals (Cordain et al., 2001). Brain tissue is a particularly rich source of both AA and DHA, while liver and muscle are good sources of AA 
and moderate sources of DHA (Cordain et al., 2001). This scenario is more likely than that proposed by Cunnane and colleagues (e.g., Cunnane and Crawford, 2003), who argue that a shore-based diet (e.g., fish and shellfish) provided the critical nutrients and energy for hominid brain expansion. Given the near complete absence of these foods in early hominid diets and the relatively low energy density of freshwater fish compared to other plant and animal sources, this hypothesis is extremely unlikely (Klein, 1999; Cordain et al., 2001).

\section{Body Composition}

Most energetic models use body mass as a single variable without taking into account its constituent components, yet there are dramatic differences among mammals in body composition, even in closely related species. Muscle mass, for example, varies from 24 to $61 \%$ of total body mass in mammals, with slow-moving arboreal mammals (e.g., sloths) occupying the low end and terrestrial carnivores (e.g., felids) occupying the high end (Grand, 1977; Calder, 1984; Muchlinski et al., 2003, in prep.). These differences in body composition contribute to variation in energy demands because of marked differences in mass-specific metabolic rates across organs and tissues. Thus, reductions in organ or tissue mass could theoretically decrease the body's overall energy costs and compensate for the high metabolic demands of the brain. This perspective forms the basis of the Expensive Tissue Hypothesis, which posits that the increased metabolic requirement of an enlarged brain among hominids is offset by a concomitant reduction in gut size since both are metabolically "expensive" tissues (Aiello and Wheeler, 1995; Aiello, 1997; Aiello et al., 2001).

Among mammals, body mass is the prime determinant of the mass of most internal organs. The heart, lungs, kidneys, liver, and spleen all scale with a coefficient nearly identical to or slightly below 1.0 and all regressions have extremely high correlation 
coefficients (Stahl, 1965). Other tissues (e.g., brain, gut, skeletal muscle, and adipose tissue), seem to be less constrained by body size and vary according to other functional demands (Calder, 1984; Schmidt-Nielsen, 1984; Muchlinski et al., 2003; Wells, 2006). In order to assess whether variation in body composition among primates contributes to the energetics of brain expansion, we compared data on gut mass and skeletal muscle mass in primates with other mammals.

Gut size and proportions are influenced by dietary factors in primates and other mammals (Chivers and Hladik, 1980; Martin et al., 1985; Sussman, 1987). Carnivorous species generally have guts that are dominated by the small intestine, folivores have an enlarged stomach or cecum and colon, and frugivores are morphologically intermediate between carnivores and folivores. Non-human primates have a fairly generalized digestive morphology, which reflects their omnivorous dietary habits; however, certain species (e.g., colobines) have morphological adaptations indicative of a more specialized diet. Most studies to date (e.g., Hladik et al., 1999) have used surface area measures rather than mass to assess gut size (but see Aiello and Wheeler, 1995); however, mass is a more appropriate measure for assessing the energetic implications of interspecific variation in body composition. It should be noted that certain mammals show considerable plasticity in gut dimensions in response to captive diets or seasonal shifts in diet, although this is not true for all species studied (Chivers and Hladik, 1980; Martin et al., 1985). While only limited research has focused on this issue in primates, Milton (2003) notes that humans and great apes display limited gut plasticity and that genetic factors are likely responsible for the divergent gut dimensions in these groups.

Results from the present study indicate that non-human primates have similar sized guts as other mammals. These results do not support our hypothesis that non-human primates have smaller guts than other mammals, and are at odds with the results of Aiello and Wheeler 
(1995). Although Aiello and Wheeler used a similar primate dataset as the present study, the mammalian sample in that study was largely based on a small number of domesticated species, especially ungulates (based on data from Brody, 1945); consequently, that study likely overestimates "average” mammalian gut size (Snodgrass et al., 1999). In contrast to the Brody (1945) dataset, the sample in the present study included a large number of mammalian species (Pitts and Bullard, 1968; Chivers and Hladik 1980).

The present study documented a total gut mass in humans significantly smaller than expected for body size, a result similar to that of other studies and reflective of the high quality diet of humans compared to other large-bodied primates (Martin et al., 1985; Aiello and Wheeler, 1995). As suggested by Aiello and Wheeler (1995), the energy cost savings of the reduced GI tract likely plays a central role in lowering overall energy costs in humans and helps to balance the metabolic costs of an enlarged brain. Studies that have examined gut proportions based on surface area have documented significant differences between humans and other primates, including great apes (e.g., Milton, 1987). The human gut is dominated by the small intestine while the colon is relatively small; in contrast, great apes have relatively modest small intestines and considerably larger colons. These disparities in size and proportions reflect the human adaptation for consumption of a low volume of energy-dense and easily digestible foods, while great apes are adapted for consumption of a fairly low quality diet with greater quantities of difficult to digest plant material. Studies that compared the surface area of gut segments place humans closest to carnivores or to mixed carnivorefrugivores (Martin et al., 1985; Sussman, 1987).

As dietary quality increased during human evolution, the gut likely responded by becoming smaller in overall size and shifting in its proportions in order to maximize extraction from energy and nutrient rich foods. The improved ability of members of the genus Homo to process foods extra-orally (i.e., using tools) may also have contributed to the 
reduction of gut (and tooth) size (Milton and Demment, 1988). It seems unlikely that the small human gut is the result of direct selection to decrease metabolic costs and offset the elevated demands of increased brain size, but instead this metabolic balancing was likely an epiphenomenon of increased dietary quality (e.g., animal foods) selecting for smaller gut size (Aiello and Wheeler, 1995; Snodgrass et al., 1999).

The functional dimensions of variation in skeletal muscle mass among primates and other mammals are poorly understood, although studies by Grand (e.g., 1977, 1978) documented associations between muscularity (i.e., the proportion of total body weight represented by skeletal muscle) and locomotor habits. In general, terrestrial species are more muscular than arboreal species (Grand, 1978). Terrestrial mammals tend to emphasize quick acceleration, attainment of more rapid speeds, and long-distance travel; thus, increased muscularity is likely an adaptation to enhance locomotor performance in order to improve food acquisition capabilities and predator avoidance. Arboreal mammals utilize a strategy that emphasizes locomotor flexibility, passive mechanisms, and reduced activity levels; thus, low muscularity reduces energy costs through decreased RMR and by minimizing the relatively high metabolic costs associated with arboreal movement (Grand, 1978; Elton et al., 1999). Given the arboreal heritage of primates, we hypothesized that primates would have lower levels of skeletal muscle mass compared to non-primate mammals.

Our results indicate that non-human primates are "undermuscled" compared to other mammals, having significantly lower levels of skeletal muscle mass for a given body mass; these results are consistent with our hypothesis. The relatively low levels of skeletal muscle mass may be related to the arboreal heritage of the primate order as, among mammals, arboreal species tend to have lower levels of muscularity (Grand, 1978). Humans fall slightly below the primate regression line, although there are large differences by sex with human females less muscular than males. Relatively low muscularity in humans may reflect a 
locomotor adaptation to reduce RMR and the costs associated with physical activity. The metabolic costs of skeletal muscle are relatively low at rest ( $13 \mathrm{kcal} / \mathrm{kg} / \mathrm{day})$, and thus small decreases in muscularity are unlikely to substantially lower RMR. However, during physical activity muscle metabolism can increase by 100 fold (McArdle et al., 2001). An alternative explanation is that low muscularity, especially among human females, results from increased levels of adipose tissue compared to men ( $25 \%$ vs. $13 \%$ on average in non-Western populations; Wells, 2006). As noted by Aiello and Wells (2002), the extent of adiposity in humans (females and males) may partially explain the "location" of humans in interspecific studies of RMR and body mass scaling; greater quantities of adipose tissue, with its low metabolic rate, has the effect of lowering relative metabolic rate.

The extent of human fatness has important implications for the energetics of encephalization. Human adults, including non-Western populations, are fatter than most freeliving primates and tropically living mammals (Pond, 1998; Wells, 2006). Energy storage is the primary function of white adipose tissue in humans and other terrestrial mammals; in contrast, aquatic mammals (e.g., cetaceans) apparently store adipose tissue at least in part as an adaptation to cold stress (Kuzawa, 1998; Pond, 1998). The human ability to readily store energy in the form of adipose tissue is a nutritional adaptation to buffer against long-term (e.g., seasonal or periodic) decreases in energy availability. Energy buffering is especially critical during infancy, when the metabolic costs for physical growth and brain metabolism are extremely high (Kuzawa, 1998; Leonard et al., 2003). These metabolic demands are reflected in our unique developmental pattern of fat deposition: human infants are born with high levels of adiposity and continue to gain fat during the first 6 months of postnatal life (Dewey et al., 1993; Kuzawa, 1998; Wells, 2006). In addition, human sex differences in adiposity are shaped by differences in reproductive strategies, given that the enormous 
energetic costs of pregnancy and lactation are borne largely by females (FAO/WHO/UNU, 1985; Tracer, 1991; Valeggia and Ellison, 2001).

What is most remarkable about human adiposity is our extreme fatness at birth and during early life. At birth, human infants are approximately 15\% body fat (Kuzawa, 1998). Compared to the few mammalian species for which published data exist, humans are fatter than domesticated species (e.g., pigs [1.3\%]), wild species (e.g., baboons [3\%]), and even pinnipeds (e.g., harp seals [10.4\%]) (Kuzawa, 1998). Unlike other mammals, humans begin depositing fat prenatally and then continue to accumulate fat during the first 6 to 9 months of postnatal life (Dewey et al., 1993; Kuzawa, 1998) (see Table 3). At its peak in infancy, fat represents on average 25 to over 30\% of total body weight (Kuzawa, 1998; Butte et al., 2000).

This unique developmental pattern of fat deposition in humans likely reflects an adaptation to preserve cerebral metabolism in the face of the high metabolic demands of the relatively large brain; these energy demands are obligate and cannot be downregulated in times of energy scarcity (Kuzawa, 1998). The brain relies on glucose as its primary energy source, yet humans have a limited capacity to store glucose. During times of reduced energy intake (e.g., starvation), the primary cerebral energy source is shifted to ketone bodies, which are produced through the mobilization of adipose stores, as well as glucose derived from endogenous production through hepatic gluconeogenesis (Fernstrom and Fernstrom, 2003). The brain is enormously costly in the developing infant, accounting for over $50 \%$ of RMR (Holiday, 1986) (see Table 3). It is not simply the relative size of the infant brain that explains the high metabolic costs of the brain early in life, but also the rate of energy utilization. Recent studies demonstrate that developmental synaptic overproduction and subsequent pruning results in cerebral metabolic costs that are higher in sub-adults compared to adults - twofold higher glucose utilization uptake rates at 4 years old — and that these rates 
remain relatively elevated until much later in childhood than previously recognized (Chugani, 1998).

The growing brain is particularly vulnerable to disruptions in energy supply during the nutritional transitions that occur at birth (before the consumption of adequate quantities of breastmilk) and weaning (with complete cessation of the consumption of breastmilk); adipose tissues provide a relatively long-term buffer against limitations in energy intake (Kuzawa, 1998; Pond, 1998; Wells, 2006). The functional link between brain development and body fat is supported by an association between brain size and body fat at birth among mammals. Those species with relatively large adult brain size have larger fat stores at birth; this buffers them against energy disruptions that occur prior to the establishment of adequate energy intake from suckling (Kuzawa, 1998; Leonard et al., 2003).

The other period of heightened vulnerability to nutritional disruption (weaning) also shapes the developmental pattern of fat deposition. In healthy full-term infants fed solely on breast milk, growth typically begins to falter at approximately six months of age; supplemental foods (liquids and solids) are typically introduced by this age in virtually all human populations (Whitehead and Paul, 2000; Sellen, 2001; Foote and Marriott, 2003; Kennedy, 2005). Supplemented breastfeeding then continues in most non-Western populations until weaning at 2 to 3 years of age. This abbreviated weaning schedule departs dramatically from the presumed ancestral condition of protracted lactation in the great apes (e.g., 5 years in P. troglodytes). Weaning must occur around this time in humans because the energy and nutrient demands of the relatively large infant brain cannot be met through supplemented breastfeeding (Kuzawa, 1998; Sellen, 2001; Kennedy, 2005). This life history strategy, however, is risky because of the immaturity of the immune and digestive systems and the overall dependence of the child. Consequently, in most traditional human populations, morbidity and mortality rates are high at this age due to the interaction of poor 
nutritional/dietary quality and increased infectious disease exposure from food and water. Adipose stores accumulated in early infancy provide a critical buffer against the energy disruptions that occur with nutritional transition and disease (e.g., diarrhea).

The successful shift to weaning at an earlier age requires weanlings to consume an energy-dense, easily digestible diet to sustain the high metabolic costs of the large brain. High quality foods, such as meat and other animal foods, would have been especially valuable for providing adequate calories and nutrients to the growing child with their immature dentition and digestive system (Bogin, 1999; Milton, 1999; Kennedy, 2005). Consumption of large quantities of animal foods by young children would have entailed dependence on others for acquisition and preparation (Bogin, 1999; Aiello and Key, 2002). A life history shift that slows growth rates during childhood and the juvenile period also would have helped lower energy costs and allowed for enhanced learning, which would have been particularly important for acquiring hunting and extractive foraging skills (Bogin, 1999; Aiello and Wells, 2002; Kennedy, 2005).

\section{Body Size}

Given the limitations inherent in the fossil record, we may never know conclusively when the distinct pattern of body composition emerged in human evolution. However, a considerable amount of information on body size in early hominids can be reconstructed from fossil specimens and provides useful information on the energetics of encephalization. Body size estimates derived from post-cranial fossils suggest that all australopithecine species for which we have adequate information (i.e., A. afarensis, A. africanus, A. robustus, and A. boisei) were relatively small-bodied (Table 2). Species body weights for males are estimated as 40$49 \mathrm{~kg}$ and statures as $130-150 \mathrm{~cm}$. Considerable sexual dimorphism was apparent in all australopithecines; females of each species were on average $29-34 \mathrm{~kg}$ and not taller than 125 
cm. Homo habilis (sensu strictu) was no larger in body size than the australopithecines, with male and female body weights of 37 and $32 \mathrm{~kg}$, respectively; stature is reconstructed as 131 $\mathrm{cm}$ in males and $100 \mathrm{~cm}$ in females. Presently, there is no consensus on whether any postcranial fossils can be definitively assigned to H. rudolfensis (Wood and Collard, 1999; McHenry and Coffing, 2000). Given the lack of post-cranial material to serve as a basis for body weight reconstructions, we excluded this species from our study. However, various post-cranial elements from Koobi Fora at $\sim 1.9 \mathrm{Ma}$, which indicate a fairly large body size (see McHenry and Coffing, 2000), were found in the proximity of cranial remains belonging to $H$. rudolfensis and likely belong to that species. With the appearance of $H$. erectus, body size dramatically increased and reached a weight and height comparable to modern humans; however, as noted above, some recent fossils of apparently small-bodied H. erectus (Spoor et al., 2007; Lordkipanidze et al., 2007) have complicated the picture of body size in this species. Based on presently available evidence, body size increase appears to have been most pronounced in H. erectus females; if confirmed, one of the remarkable changes in this species is the reduction in sexual dimorphism to within the range of modern humans (Leonard and Robertson, 1997; McHenry and Coffing, 2000; Aiello and Key, 2002). While some evidence suggests a shift in body proportions with the appearance of $H$. habilis (Haeusler and McHenry, 2004), a major shift in body proportions, to a linear body form with relatively long legs, was clearly in place in early representatives of H. erectus (Ruff and Walker, 1993; Lordkipanidze et al., 2007). This shift likely reflects an adaptation to maximize heat dissipation in the hot and arid environment of eastern and southern Africa (Ruff, 1993). This body size increase and shift to longer legs would have had implications for increased locomotor efficiency, and served to decrease the costs of movement between food sources (Leonard and Robertson, 1997; Steudel-Numbers, 2006). 
The larger body size of $H$. erectus would have greatly increased both maintenance (resting) and total energy demands of this species (Leonard and Robertson, 1997). Larger body size coupled with a high quality diet likely would have forced $H$. erectus to expand home ranges, further increasing total energy costs (Leonard and Robertson, 2000). Greater home ranges in this species may help explain why H. erectus was the first hominid species to disperse out of Africa (Leonard and Robertson, 2000; Antón et al., 2001, 2002). However, the costs in terms of increased energy needs were likely steep; Leonard and Robertson (1997) estimate a TEE $80-85 \%$ greater than that seen in the australopithecines. As indicated by the evolutionary success of this species in its temporal and geographic distributions, greater energy costs were clearly offset by the ability to obtain adequate dietary resources (Leonard and Robertson, 1997, 2000; Aiello and Key, 2002; Aiello and Wells, 2002).

The increase in body mass in $H$. erectus, and in particular the disproportionate increase among females, has implications for the energetics of encephalization (Leonard and Robertson, 1997; Aiello and Key, 2002; Aiello and Wells, 2002). Body size in females is a critical energetic variable because they bear virtually all the costs of reproduction, including providing energy necessary for fetal and early postnatal brain growth and maintenance and fat deposition in the offspring. An absolute increase in metabolism in females affects the ability to transfer energy in reproduction, since greater metabolic turnover allows increasing amounts of energy to be channeled to the offspring (Martin, 1996; Aiello and Key, 2002). Greater female body size also allows the delivery of a larger brained child, since several important pelvic dimensions are closely associated with stature (Ellison, 2001). Pelvic adaptations to bipedality in humans, however, place important constraints on intra-uterine growth (Rosenberg, 1992). The reduction of gestation lengths and the evolution of secondarily altricial newborns may have emerged with early members of the genus Homo as a mechanism for circumventing the pelvic constraints on intra-uterine growth. This change 
would have extended the very rapid rates of brain growth that are characteristic of fetal development into the first year of an infant's postnatal life (Martin, 1983). Such an important life history shift would have markedly increased maternal energetic demands during lactation. As a consequence, it appears that the evolution of secondary altriciality would have necessitated sufficiently large maternal body sizes that are evident in the hominid lineage only after the emergence of early Homo.

\section{Conclusions}

In summary, the relative proportion of energy allocated to brain metabolism is positively correlated with diet quality among living primates. Thus, primate species with large brains rely on relatively energy-dense diets to support their high cerebral costs. Australopithecines and other early hominids with brain sizes similar to non-human primates probably increased dietary breadth compared with closely related hominoids but do not appear to have significantly increased diet quality. Thus, dietary factors may have constrained encephalization in the earliest hominids. The remarkable expansion of the brain that began with early Homo likely required the following: 1) a shift to a higher quality diet, with a substantial quantity of animal foods; 2) an increase in body size, particularly among females, which allowed greater transfer of energy to the offspring for brain metabolism and fat deposition; and 3) increased levels of body fat early in life to act as an energy buffer for brain metabolism. Important changes in body composition also appear to have resulted from these changes. A reduction in overall gut size and a change in gut proportions was likely a consequence of the shift to a more energetically dense and easily digestible diet. In addition, decreased muscularity was likely a byproduct of increased body fatness. These reductions in gut size and muscle mass would have decreased the metabolic costs associated with somatic maintenance and partially offset increases in cerebral metabolism. 


\section{Acknowledgments}

We thank L.C. Aiello, S.C. Antón, C.W. Kuzawa, M.N. Muchlinski, and C.J. Terranova for discussions of the project. We thank D.J. Chivers for providing assistance with interpreting gastrointestinal data and for providing corrections for typesetting errors in the original paper.

\section{References}

Aiello, L.C., 1997. Brains and guts in human evolution: the expensive tissue hypothesis. Braz. J. Genet. 20, 141148.

Aiello, L.C., Bates, N., Joffe, T., 2001. In defense of the expensive tissue hypothesis. In: Falk, D., Gibson, K. (Eds.), Evolutionary Anatomy of the Primate Cerebral Cortex. Cambridge University Press, Cambridge, pp. 57-78.

Aiello, L.C., Key, C., 2002. Energetic consequences of being a Homo erectus female. Am. J. Hum. Biol. 14, $551-565$.

Aiello, L.C., Wells, J.C.K., 2002. Energetics and the evolution of the genus Homo. Annu. Rev. Anthropol. 31, $323-338$.

Aiello, L.C., Wheeler, P., 1995. The expensive-tissue hypothesis: the brain and the digestive system in human and primate evolution. Curr. Anthropol. 36, 199-221.

Antón, S.C., 2003. A natural history of Homo erectus. Yrbk. Phys. Anthropol. 46, 126-170.

Antón, S.C., 2008. Framing the question: diet and evolution in early Homo. In: Vinyard, C., Ravosa, M.J., Wall, C. (Eds.), Primate Craniofacial Function and Biology. Springer, New York, in press.

Antón, S.C., Aziz, F., Zaim, Y., 2001. Plio-Pleistocene Homo: patterns and determinants of dispersal. In: Tobias, P.V., Raath, M.A., Moggi-Cecchi, J., Doyle, G.A. (Eds.), Humanity from African Naissance to Coming Millenia. Florence University Press, Florence, pp. 91-102.

Antón, S.C., Leonard, W.R., Robertson, M.L., 2002. An ecomorphological model of the initial hominid dispersal from Africa. J. Hum. Evol. 43, 773-785. 
Antón, S.C., Spoor, F., Fellmann, C.D., Swisher, C.C., 2007. Defining Homo erectus: size considered. In: Henke, W., Tattersall, I. (Eds.), Handbook of Paleoanthropology (Volume 3). Springer-Verlag, Berlin, pp. 1655-1693.

Antón, S.C., Swisher, C.C., 2001 Evolution of cranial capacity in Asian Homo erectus. In: Indriati, E. (Ed.), A Scientific Life: Papers in Honor of Dr. T. Jacob. Bigraf Publishing, Yogyakarta, pp. 25-39.

Asfaw, B., Beyene, Y., Suwa, G., Walter, R.C., White, T.D., WoldeGabriel, G., Yemane, T., 1992. The earliest Acheulean from Konso-Gardula. Nature 360, 732-735.

Backwell, L.R., d'Errico, F., 2001. Evidence of termite foraging by Swartkrans early hominids. PNAS 98, 13581363.

Bauchot, R., Stefan, H., 1969. Encephalisation et niveau evolutif ches les simiens. Mammalia 33, 225-275.

Behrensmeyer, K., Todd, N.E., Potts, R., McBrinn, G.E., 1997. Late Pliocene faunal turnover in the Turkana basin, Kenya and Ethiopia. Science 278, 1589-1594.

Bell, R.H., 1971. A grazing ecosystem in the Serengeti. Sci. Am. 225, 86-93.

Bellomo, R.V., 1994. Methods of determining early hominid behavioral activities associated with the controlled use of fire at FxJj 20 Main, Koobi Fora. J. Hum. Evol. 27, 173-195.

Blumenschine, R.J., 1987. Characteristics of an early hominid scavenging niche. Curr. Anthropol. 28, 383-407.

Bobe, R., Behrensmeyer, A.K. 2002. Faunal change, environmental variability and late Pliocene hominin evolution. J. Hum. Evol. 42, 475-497.

Bogin, B., 1999. Patterns of Human Growth ( $2^{\text {nd }}$ ed.). Cambridge University Press, Cambridge.

Bogin, B., 2002. The evolution of human growth. In: Cameron, N. (Ed.), Human Growth and Development. Academic Press, Amsterdam, pp. 295-320.

Brain, C.K., Sillen, A., 1988. Evidence from the Swartkrans cave for the earliest use of fire. Nature 336, 464466.

Brody, S., 1945. Bioenergetics and Growth: With Special Reference to the Efficiency Complex in Domestic Animals. Reinhold Publishing, New York.

Butte, N.F., Hopkinson, J.M., Wong, W.W., Smith E.O., Ellis, K.J., 2000. Body composition during the first 2 years of life: an updated reference. Pediatr. Res. 47, 578-585.

Calder, W.A., 1984. Size, Function, and Life History. Harvard University Press, Cambridge. 
Chivers, D.J., Hladik, C.M. 1980. Morphology of the gastrointestinal tract in primates: comparisons with other mammals in relation to diet. J. Morph. 166, 337-386.

Chugani, H.T., 1998. A critical period of brain development: studies of cerebral glucose utilization with PET. Prevent. Med. 27, 184-197.

Cordain, L., Brand Miller, J., Eaton, S.B., Mann, N., Holt, S.H.A., Speth, J.D., 2000. Plant-animal subsistence ratios and macronutrient energy estimations in worldwide hunter-gatherer diets. Am. J. Clin. Nutr. 71, 682-692.

Cordain, L., Watkins, B.A., Mann, N.J., 2001. Fatty acid composition and energy density of foods available to African hominids: Evolutionary implications for human brain development. World Rev. Nutr Diet 90, 144-161.

Cunnane, S.C., Crawford, M.A. 2003. Survival of the fattest. Comp Biochem. Physiol 136A, 17-36.

deMenocal, P.B., 1995. Plio-Pleistocene African climate. Science 270, 53-59.

deMenocal, P.B., 2004. African climate change and faunal evolution during the Pliocene-Pleistocene. Earth Planet. Sc. Lett. 220, 3-24.

Dewey, K.G., Heinig, M.J., Nommsen, L.A., Peerson, J.M., Lonnderdal, B., 1993. Breast-fed infants are leaner than formula-fed infants at 1 y of age: the Darling study. Am. J. Clin. Nutr. 52, 140-145.

Elia, M., 1992. Organ and tissue contribution to metabolic rate. In: Kinney, J.M., Tucker, H.N. (Eds.), Energy Metabolism: Tissue Determinants and Cellular Corollaries. Raven Press, New York, pp. 61-79.

Ellison, P.T., 2001. On Fertile Ground: A Natural History of Human Reproduction. Harvard University Press, Cambridge.

Elton, S., Foley, R., Ulijaszek, S.J., 1998. Habitual energy expenditure of human climbing and clambering. Ann. Hum. Biol. 25, 523-531.

Englyst, K.N., Englyst, H.N., 2005. Carbohydrate bioavailability. Br. J. Nutr. 94, 1-11.

FAO/WHO/UNU. 1985. Energy and Protein Requirements. WHO Technical Report Series \#724. World Health Organization, Geneva.

Fernstrom, J.D., Fernstom, M.H., 2003. Nutrition and the brain. In: Gibney, M., MacDonald, I., Roche, H.M. (Eds.), Nutrition and Metabolism. Blackwell Publishing, Ames, pp. 145-167. 
Fish, J.L., Lockwood, C.A., 2003. Dietary constraints on encephalization in primates. Am. J. Phys. Anthropol. 120: $171-181$.

Foote, K.D., Marriott, L.D., 2003. Weaning of infants. Arch. Dis. Child. 88, 488-492.

Gabunia, L., Vekua, A., Lordkipanidze, D., Swisher, C.C., Ferring, R., Justus, A., Nioradze, M., Tvalchrelidze, M., Antón, S.C., Bosinski, G., Joris, O., de Lumley, M.-A., Majsuradze, G., Mouskhelishivili, A., 2000. Earliest Pleistocene cranial remains from Dmanisi, Republic of Georgia: taxonomy, geological setting, and age. Science 288, 1019-1025.

Gabunia, L., Antón, S.C., Lordkipanidze, D., Vekua, A., Justus, A., Swisher, C.C., 2001. Dmanisi and dispersal. Evol. Anthropol. 10, 158-170.

García-Alonso, A., Goñi, I., 2000. Effect of processing on potato starch: in vitro availability and glycemic index. Nahrung 44, 19-22.

Gaulin, S.J.C., 1979. A Jarman/Bell model of primate feeding niches. Hum. Evol. 7, 1-20.

Grand, T.I., 1977. Body weight: its relation to tissue composition, segment distribution, and motor function. Am. J. Phys. Anthropol. 47, 211-239.

Grand, T.I., 1978. Adaptations of tissues and limb segments to facilitate moving and feeding in arboreal folivores. In: Montgomery, G.G. (Ed.), The Ecology of Arboreal Folivores. Smithsonian, Washington, pp. 231-241.

Haeusler, M., McHenry, H.M., 2004. Body proportions of Homo habilis reviewed. J. Hum. Evol. 46, 433-465.

Harris, J.W.K., Capaldo, S. 1993. The earliest stone tools: their implications for an understanding of the activities and behavior of late Pleistocene hominids. In: Berthelet, A., Chavaillon, J. (Eds.), The use of Tools by Human and Nonhuman Primates. Oxford Science Publications, Oxford, pp. 196-220.

Hatley, T., Kappelman, J., 1980. Bears, pigs, and Plio-Pleistocene hominids: a case for the exploitation of below-ground good resources. Hum. Ecol. 8, 371-387.

Hladik, C.M., Chivers, D.J., Pasquet, P., 1999. On diet and gut size in non-human primates and humans: is there a relationship to brain size? Curr. Anthropol. 40, 695-697.

Holliday, M.A., 1986. Body composition and energy needs during growth. In: Falkner, F., Tanner, J.M. (Eds.), Human Growth: A Comprehensive Treatise, $2^{\text {nd }}$ ed., Vol. 2. Plenum Press, New York, pp. 101-117.

Hopley, P.J., Weedon, G.P., Marshall, J.D., Herries, A.I.R., Latham, A.G., Kuykendall, K.L., 2007. High- and low-latitude orbital forcing of early hominin habitats in South Africa. Earth Planet Sc. Lett. 256, 419432. 
Jarman, P.J., 1974. The social organization of antelope in relation to their ecology. Behaviour 58, 215-267.

Jerison, H.J., 1973. The Evolution of the Brain and Intelligence. Academic Press, New York.

Kaplan, H., Hill, K., Lancaster, J., Hurtado, A.M., 2000. A theory of human life history evolution: diet, intelligence, and longevity. Evol. Anthropol. 9, 156-185.

Kappeler, P.M., 1996. Causes and consequences of life-history variation among strepsirhine primates. Am. Nat. $148,868-891$.

Kay, R.F., 1984. On the use of anatomical features to infer foraging behavior in extinct primates. In: Rodman, P.S., Cant, J.G.H. (Eds.), Adaptations for Foraging in Nonhuman Primates. Columbia University Press, New York, pp. 21-53.

Kennedy, G.E. 2005. From the ape's dilemma to the weanling's dilemma: early weaning and its evolutionary context. J. Hum. Evol. 48, 123-145.

Kleiber, M., 1961. The Fire of Life. Wiley, New York.

Klein, R.G., 1999. The Human Career. University of Chicago Press, Chicago.

Kuzawa, C., 1998. Adipose tissue in human infancy and childhood: an evolutionary perspective. Yrbk. Phys. Anthropol. 41, 177-209.

Laden, G., Wrangham, R.W., 2005. The rise of the hominids as an adaptive shift in fallback foods: plant underground storage organs (USOs) and australopith origins. J. Hum. Evol. 49, 482-498.

Leonard, W.R., Robertson, M.L., 1992. Nutritional requirements and human evolution: a bioenergetics model. Am. J. Hum. Biol. 4, 179-195.

Leonard, W.R., Robertson, M.L., 1994. Evolutionary perspectives on human nutrition: the influence of brain and body size on diet and metabolism. Am. J. Hum. Biol. 6, 77-88.

Leonard W.R., Robertson, M.L., 1997. Comparative primate energetics and hominid evolution. Am. J. Phys. Anthropol. 102, 265-281.

Leonard, W.R., Robertson, M.L., 2000. Ecological correlates of home range variation in primates: implications for hominid evolution. In: Boinski, S., Garber, P. (Eds.) On the Move: How and Why Animals Travel in Groups. University of Chicago Press, Chicago, pp. 628-648.

Leonard, W.R., Robertson, M.L., Snodgrass, J.J., Kuzawa, C.W., 2003. Metabolic correlates of hominid brain expansion. Comp. Biochem. Physiol. 136A, 5-15.

Leonard, W.R., Robertson M.L., Snodgrass, J.J., 2007. Energetic models of human nutritional evolution. In: 
Ungar, P.S. (Ed.) Evolution of the Human Diet: The Known, the Unknown, and the Unknowable. Oxford University Press, Oxford, pp. 344-359.

Leonard, W.R., Ulijaszek, S.J., 2002. Energetics and evolution: an emerging research domain. Am. J. Hum.

Biol. 14, 547-550.

Lordkipanidze, D., Jashashvili, T., Vekua, A., Ponce de León, M.S., Zollikofer, C.P.E., Rightmire, G.P., Pontzer, H., Ferring, R., Oms, O., Tappen, M., Bukhsianidze, M., Agusti, J., Kahlke, R., Kiladze, G., Martinez-Navarro, B., Mouskhelishvili, A., Nioradz, M., Rook, L. 2007. Postcranial evidence from early Homo from Dmanisi, Georgia. Nature 449: 305-310.

Marlowe, F.W., 2005. Hunter-gatherers and human evolution. Evol. Anthropol. 14, 54-67.

Martin, R.D., 1983. Human Brain Evolution in an Ecological Context. American Museum of Natural History, New York.

Martin, R.D., 1990. Primate Origins and Evolution: A Phylogenetic Reconstruction. Chapman \& Hall, London. Martin, R.D., 1996. Scaling of the mammalian brain: the maternal energy hypothesis. News Physiol. Sci. 11, $149-156$.

Martin, R.D., Chivers, D.J., MacLarnon, A.M., Hladik, C.M. 1985. Gastrointestinal allometry in primates and other mammals. In: Jungers, W.L. (Ed.), Size and Scaling in Primate Biology. Plenum Press, New York, pp. 61-89.

McArdle, W.D., Katch, F.I., Katch, V.L., 2001. Exercise Physiology: Energy, Nutrition, and Human Performance. Lippincott, Williams, \& Wilkins, Philadelphia.

McHenry, H.M., 1994a. Tempo and mode in human evolution. PNAS 91, 6780-6786.

McHenry, H.M., 1994b. Behavioral ecological implications of early hominid body size. J. Hum. Evol. 27, 7787.

McHenry, H.M., Coffing, K., 2000. Australopithecus to Homo: transformations in body and mind. Ann. Rev. Anthropol. 29, 125-146.

McNab, B.K., 2002. The Physiological Ecology of Vertebrates: A View from Energetics. Cornell University Press, Ithaca.

McNab, B.K., Wright, P.C., 1987. Temperature regulation and oxygen consumption in the Philippine tarsier Tarsius syrichta. Physiol. Zoo. 60, 596-600.

Milton, K., 1987. Primate diets and gut morphology: implications for hominid evolution. In: Harris, M., Ross, 
E.B. (Eds.), Food and Evolution: Toward a Theory of Human Food Habits. Temple University Press, Philadelphia, pp. 93-115.

Milton, K., 1999. A hypothesis to explain the role of meat-eating in human evolution. Evol. Anthropol. 8, 11-21.

Milton, K., 2003. The critical role played by animal source foods in human (Homo) evolution. J. Nutr. 133, 3886S-3892S.

Milton, K., Demment, M., 1988. Digestive and passage kinetics of chimpanzees fed high- and low-fiber diets and comparison with human data. J. Nutr. 118, 1-7.

Muchlinski, M.N., Snodgrass, J.J., Terranova, C.J., 2003. Scaling of muscle mass in primates. Am. J. Phys. Anthropol. (Suppl.) 36, 155.

Muchlinski, M.N., Snodgrass, J.J., Terranova, C.J., in preparation. Muscle mass scaling in primates and other mammals. J. Mamm. Evol.

Pennisi, E., 1999. Did cooked tubers spur the evolution of big brains? Science 283, 2004-2005.

Pitts, G.C., Bullard, T.R., 1968. Some interspecific aspects of body composition in mammals. In: National Research Council (Ed.), Body Composition in Animals and Man. National Academy of Sciences Press, Washington, pp. 45-79.

Plummer, T., 2004. Flaked stones and old bones: biological and cultural evolution at the dawn of technology. Yrbk. Phys. Anthropol. 47, 118-164.

Pond, C.M., 1998. The Fats of Life. Cambridge University Press, Cambridge.

Potts, R., 1998. Environmental hypotheses of hominin evolution. Yrbk. Phys. Anthropol. 41, 93-136.

Preece, R.C., Gowlett, J.A.J., Parfitt, S.A., Bridgland, D.R., Lewis, S.G., 2006. Humans in the Hoxnian: habitat, context and fire use at Beeches Pit, West Stow, Suffolk, UK. J. Quaternary Sci. 21, 485-496.

Richard, A.F., 1985. Primates in Nature. WH Freeman, New York.

Rogers, M.J., Harris, J.W.K., Feibel, C.S.S., 1994. Changing patterns of land use by Plio-Pleistocene hominids in the Lake Turkana basin. J. Hum. Evol. 27, 139-158.

Rosenberg, K.R., 1992. The evolution of modern human childbirth. Yrbk. Phys. Anthropol. 35, 89-124.

Rowe, N., 1996. The Pictorial Guide to Living Primates. Pogonias Press, New York.

Ruff, C.B., 1993. Climatic adaptation and hominid evolution: the thermoregulatory imperative. Evol. Anthropol. 2, 53-60.

Ruff, C.B., Walker, A., 1993. Body size and shape. In: Walker, A., Leakey, R. (Eds.), The Nariokotome Homo erectus Skeleton. Harvard University Press, Cambridge, pp. 234-265. 
Sailer, L.D., Gaulin. S.J.C., Boster. J.S., Kurland, J.A., 1985. Measuring the relationship between dietary quality and body size in primates. Primates 26, 14-27.

Schmidt-Nielsen, K., 1984. Scaling: Why is Animal Size so Important? Cambridge University Press, Cambridge.

Schoeninger, M.J., Bunn, H.T., Murray, S.S., Marlett, J.A., 2001. Nutritional composition of some wild plant foods and honey used by Hadza foragers of Tanzania. J. Food Comp. Anal. 14, 3-13.

Sellen, D.W., 2001. Comparison of infant feeding patterns reported for nonindustrial populations with current recommendations. J. Nutr. 131, 2707-2715.

Semaw, S., Rogers, M.J, Quade, J., Renne, P.R., Butler, R.F., Dominguez-Rodrigo, M., Stout, D., Hart, W.S., Pickering, T., Simpson, S.W, 2003. 2.6-million-year-old stone tools and associated bones from OGS-6 and OGS-7, Gona, Afar, Ethiopia. J. Hum. Evol. 45, 169-177.

Snodgrass, J.J., Leonard, W.R., Robertson, M.L., 1999. Interspecific variation in body composition and its influence on metabolic variation in primates and other mammals. Am. J. Phys. Anthropol. (Suppl.) 28, 255.

Snodgrass, J.J., Leonard, W.R., Robertson, M.L., 2007. Primate bioenergetics. In: Ravosa, M.J., Dagosto, M. (Eds.), Primate Origins: Adaptations and Evolution. Springer, New York, pp. 703-737.

Sponheimer, M., Lee-Thorp, J., de Ruiter, D., Codron, D., Codron, J., Baugh, A.T., Thackeray, F., 2005.

Hominins, sedges, and termites: new carbon isotope data from Sterkfontein valley and Kruger National Park. J. Hum. Evol. 48, 301-312.

Spoor, F., Leakey, M.G., Gathogo, P.N., Brown, F.H., Antón, S.C., McDougall, I., Kiarie, C., Manthi, F.K., Leakey, L.N., 2007. Implications of new early Homo fossils from Ileret, east of Lake Turkana, Kenya. Nature 448, 688-691.

Stahl, W.R., 1965. Organ weights in primates and other mammals. Science 150, 1039-1042.

Stanford, C.B., 1996. The hunting ecology of wild chimpanzees: implications for the evolutionary ecology of Pliocene hominids. Am. Anthropol. 98, 96-113.

Stephan, H., Frahm, H., Baron, G., 1981. New and revised data on volumes of brain structures in insectivores and primates. Folia Primatol. 35, 1-29.

Steudel-Numbers, K.L., 2006. Energetics in Homo erectus and other early hominins: the consequences of increased lower-limb length. J. Hum. Evol. 51, 445-453.

Straus, L.G., 1989. On early hominid use of fire. Curr. Anthropol. 30, 488-491. 
Sussman, R.W., 1987. Species-specific dietary patterns in primates and human dietary adaptations. In: Kinzey, W. (Ed.), Evolution of Human Behavior: Primate Models. SUNY Press, Albany, pp. 151-179.

Tagliabue, A., Raben, A., Heijnen, M.L., Duerenberg, P., Pasquali, E., Astrup, A., 1995. The effect of raw potato starch on energy expenditure and substrate oxidation. Am. J. Clin. Nutr. 61, 1070-1075.

Teaford, M.F., Ungar, P.S., 2000. Diet and the evolution of the earliest human ancestors. PNAS 97: 1350613511.

Thompson, S.D., Power, M.L., Rutledge, C.E., Kleiman, D.G., 1994. Energy metabolism and thermoregulation in the golden lion tamarin (Leontopithecus rosalia). Folia Primatol. 63, 131-143.

Tipton, I.H., Cook, M.J., 1969. Weight of Total Gastrointestinal Tract and Its Subfractions. Oak Ridge National Laboratories, Oak Ridge.

Tracer, D.P., 1991. Fertility-related changes in maternal body composition among the Au of Papua New Guinea. Am. J. Phys. Anthropol. 85, 393-405.

Valeggia, C.R., Ellison, P.T., 2001. Lactation, energetics and postpartum fecundity. In: Ellison, P.T. (Ed.), Reproductive Ecology and Human Evolution. Aldine, New York, pp. 85-105.

Wang, Z., Moonseong, H., Lee, R.C., Kotler, D.P., Withers, R.T., Heymsfield S.B., 2001. Muscularity in human adults: proportion of adipose tissue-free body mass in skeletal muscle. Am. J. Hum. Biol. 13, 612-619.

Weiner, S., Qunqu, X., Goldberg, P., Liu, J., Bar-Yosef, O., 1998. Evidence for the use of fire at Zhoukoudian, China. Science 281, 251-253.

Wells, J.C.K., 2006. The evolution of human fatness and susceptibility to obesity: an ethological approach. Biol. Rev. 81, 183-205.

Whitehead, R.G., Paul, A.A., 2000. Long-term adequacy of exclusive breast-feeding: how scientific research has led to revised opinions. Proc. Nutr. Soc. 59, 17-23.

Wood, B., Collard, M., 1999. The human genus. Science 284, 65-71.

Wrangham, R.W., 2007. The cooking enigma. In: Ungar, P.S. (Ed.), Evolution of the Human Diet: The Known, the Unknown, and the Unknowable. Oxford University Press, Oxford, pp. 308-323.

Wrangham, R.W., Conklin-Brittain, N.L., 2003. The biological significance of cooking in human evolution. Comp. Biochem. Physiol. A 136: 35-46.

Wrangham, R.W., Jones, J.H., Laden, G., Pilbeam, D. Conklin-Brittain, N.L., 1999. The raw and the stolen: cooking and the ecology of human origins. Curr. Anthropol. 40, 567-594. 
Wynn, J.G., 2004. Influence of Plio-Pleistocene aridification on human evolution: evidence from paleosols from the Turkana Basin, Kenya. Am. J. Phys. Anthropol. 123, 106-118. 
Table 1. Metabolic rate, body mass, brain mass, and diet quality (DQ) in primates. ${ }^{a}$

\begin{tabular}{|c|c|c|c|c|c|}
\hline \multirow[b]{2}{*}{ Species } & \multicolumn{2}{|c|}{ Metabolic Data } & \multicolumn{2}{|c|}{ Brain Data } & \multirow{2}{*}{$\frac{\text { Dietary Data }}{\mathrm{DQ}}$} \\
\hline & $\begin{array}{r}\mathrm{RMR} \\
\mathrm{kcal} / \mathrm{d}\end{array}$ & $\begin{array}{c}\text { Body Mass } \\
\mathrm{kg}\end{array}$ & $\begin{array}{c}\text { Brain Mass } \\
\quad g\end{array}$ & $\begin{array}{c}\text { Body Mass } \\
\text { kg }\end{array}$ & \\
\hline Alouatta palliata & 231.9 & 4.670 & 51 & 6.400 & 136 \\
\hline Aotus trivirgatus & 52.4 & 1.020 & 16 & 0.850 & 177.5 \\
\hline Arctocebus calabarensis & 15.2 & 0.206 & 7.2 & 0.323 & 327.5 \\
\hline Callithrix geoffroyi & 27.0 & 0.225 & 7.6 & 0.280 & 235 \\
\hline Callithrix jacchus & 22.8 & 0.356 & 7.6 & 0.280 & 235 \\
\hline Cebuella pygmaea & 10.1 & 0.105 & 4.5 & 0.140 & 249.5 \\
\hline Cercopithecus mitis & 407.7 & 8.500 & 76 & 6.500 & 201.5 \\
\hline Cercocebus torquatus & 196.2 & 4.000 & 104 & 7.900 & 234 \\
\hline Cheirogaleus medius & 22.7 & 0.300 & 3.1 & 0.177 & \\
\hline Colobus guereza & 357.9 & 10.450 & 73 & 7.000 & 126 \\
\hline Erythrocebus patas & 186.9 & 3.000 & 118 & 8.000 & \\
\hline Eulemur fulvus & 42.0 & 2.397 & 25.2 & 2.397 & 129 \\
\hline Euoticus elegantulus & 25.1 & 0.260 & 7.2 & 0.274 & 230 \\
\hline Galago moholi & 13.9 & 0.155 & & & \\
\hline Galago senegalensis & 18.1 & 0.215 & 4.8 & 0.186 & 278 \\
\hline Galagoides demidoff & 6.3 & 0.058 & 3.4 & 0.081 & 305 \\
\hline Homo sapiens & 1400.0 & 53.500 & 1295 & 53.500 & 263 \\
\hline Hylobates lar & 123.4 & 1.900 & 102 & 6.000 & 181 \\
\hline Lemur catta & 45.1 & 2.678 & 25.6 & 2.678 & 166 \\
\hline Leontopithecus rosalia & 51.1 & 0.718 & & & \\
\hline Lepilemur ruficaudatus & 27.6 & 0.682 & 7.6 & 0.682 & 149 \\
\hline Loris tardigradus & 14.8 & 0.284 & 6.6 & 0.322 & 327.5 \\
\hline Macaca fascicularis & 400.9 & 7.100 & 74 & 5.500 & 200 \\
\hline Macaca fuscata & 485.4 & 9.580 & 84 & 5.900 & 223 \\
\hline Macaca mulatta & 231.9 & 5.380 & 110 & 8.000 & 159 \\
\hline Microcebus murinus & 4.9 & 0.054 & 1.8 & 0.054 & \\
\hline Nycticebus coucang & 32.4 & 1.380 & 12.5 & 0.800 & \\
\hline Otolemur crassicaudatus & 47.6 & 0.950 & 10.3 & 0.850 & 195 \\
\hline Otolemur garnettii & 47.8 & 1.028 & & & 275 \\
\hline Pan troglodytes & 581.9 & 18.300 & 420 & 46.000 & 178 \\
\hline Papio anubis & 342.9 & 9.500 & 205 & 26.000 & 207 \\
\hline Papio cynacephalus & 668.9 & 14.300 & 195 & 19.000 & 184 \\
\hline Papio papio & 297.3 & 6.230 & 190 & 18.000 & \\
\hline Papio ursinus & 589.3 & 16.620 & 190 & 18.000 & 189.5 \\
\hline Perodicticus potto & 41.3 & 1.000 & 14 & 1.150 & 190 \\
\hline Pongo pygmaeus & 569.1 & 16.200 & 370 & 55.000 & 172.5 \\
\hline Propithecus verreauxi & 86.8 & 3.080 & 26.7 & 3.480 & 200 \\
\hline Saguinus geoffroyi & 50.5 & 0.500 & 10 & 0.380 & 263 \\
\hline Saimiri sciureus & 68.8 & 0.850 & 22 & 0.680 & 323 \\
\hline Tarsius syrichta & 8.9 & 0.113 & & & 350 \\
\hline Varecia variegata & 69.9 & 3.512 & 34.2 & 3.512 & \\
\hline
\end{tabular}

${ }^{\mathrm{a}}$ Data sources: Bauchot and Stephan, 1969; Stephan et al., 1981; Jerison, 1973; Richard, 1985; Sailer et al., 1985; McNab and Wright, 1987; Leonard and Robertson, 1994; Thompson et al., 1994; Kappeler, 1996; Rowe, 1996 
Table 2. Geological ages (millions of years ago), brain size $\left(\mathrm{cm}^{3}\right)$, reconstructed male and female body mass $(\mathrm{kg})$, and postcanine tooth size (surface area; $\mathrm{mm}^{2}$ ) for selected fossil hominids. ${ }^{\text {a }}$

\begin{tabular}{lccccc}
\hline & \multirow{2}{*}{$\begin{array}{c}\text { Geological age } \\
\text { Species }\end{array}$} & $\begin{array}{c}\text { Brain size } \\
(\mathbf{m y a})\end{array}$ & $\begin{array}{c}\text { Male } \\
(\mathbf{( k g )})\end{array}$ & $\begin{array}{c}\text { Female } \\
(\mathbf{k g})\end{array}$ & $\begin{array}{c}\text { Postcanine tooth size } \\
\left(\mathbf{m m}^{\mathbf{2}}\right)\end{array}$ \\
\hline A. afarensis & $3.9-3.0$ & 438 & 45 & 29 & 460 \\
A. africanus & $3.0-2.4$ & 452 & 41 & 30 & 516 \\
A. boisei & $2.3-1.4$ & 521 & 49 & 34 & 756 \\
A. robustus & $1.9-1.4$ & 530 & 40 & 32 & 588 \\
Homo habilis (sensu strictu) & $1.9-1.6$ & 612 & 37 & 32 & 478 \\
H. erectus (early) & $1.8-1.5$ & 863 & 66 & 54 & 377 \\
H. erectus (late) & $0.5-0.3$ & 980 & 60 & 55 & 390 \\
H. sapiens & $0.4-0.0$ & 1350 & 58 & 49 & 334 \\
\hline
\end{tabular}

${ }^{a}$ Data from McHenry \& Coffing (2000), except for Homo erectus. Early H. erectus brain size is the average of African specimens as presented in McHenry (1994b), Indonesian specimens from Antón and Swisher (2001) and Georgian specimens from Gabunia et al. (2000, 2001). Data for late H. erectus are from McHenry (1994a). 
Table 3. Body mass (kg), brain mass (g), percent body fat (\%), resting metabolic rate (RMR; kcal/day), and percent of RMR allocated to brain metabolism (Brain MR; \%) for humans of various ages. ${ }^{\text {a }}$

\begin{tabular}{lccccc}
\hline Age & $\begin{array}{c}\text { Body mass } \\
(\mathbf{k g})\end{array}$ & $\begin{array}{c}\text { Brain mass } \\
(\mathbf{g})\end{array}$ & $\begin{array}{c}\text { Body fat } \\
(\boldsymbol{\%})\end{array}$ & $\begin{array}{c}\text { RMR } \\
(\mathbf{k c a l} / \mathbf{d a y})\end{array}$ & $\begin{array}{c}\text { Brain MR } \\
(\boldsymbol{\%})\end{array}$ \\
\hline Newborn & 3.5 & 475 & 16 & 161 & 87 \\
3 months & 5.5 & 650 & 22 & 300 & 64 \\
18 months & 11.0 & 1045 & 25 & 590 & 53 \\
5 years & 19.0 & 1235 & 15 & 830 & 44 \\
10 years & 31.0 & 1350 & 15 & 1160 & 34 \\
Adult male & 70.0 & 1400 & 11 & 1800 & 23 \\
Adult female & 50.0 & 1360 & 20 & 1480 & 27 \\
\hline
\end{tabular}

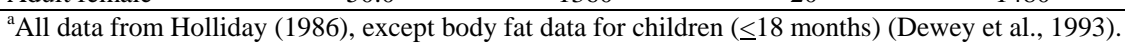




\section{Figure Legends}

Figure 1. Log-log plot of total gastrointestinal mass (g) vs. body mass (kg) in primates and non-primate mammals. For additional information on sample, see Snodgrass et al., in prep.

Figure 2. Log-log plot of muscle mass (g) vs. body mass ( $\mathrm{kg}$ ) for primates. Humans fall below the primate (standardized residual $=-0.65$ ), indicating they are undermuscled compared to other primates. For additional information on the sample, see Muchlinski et al., in prep. 


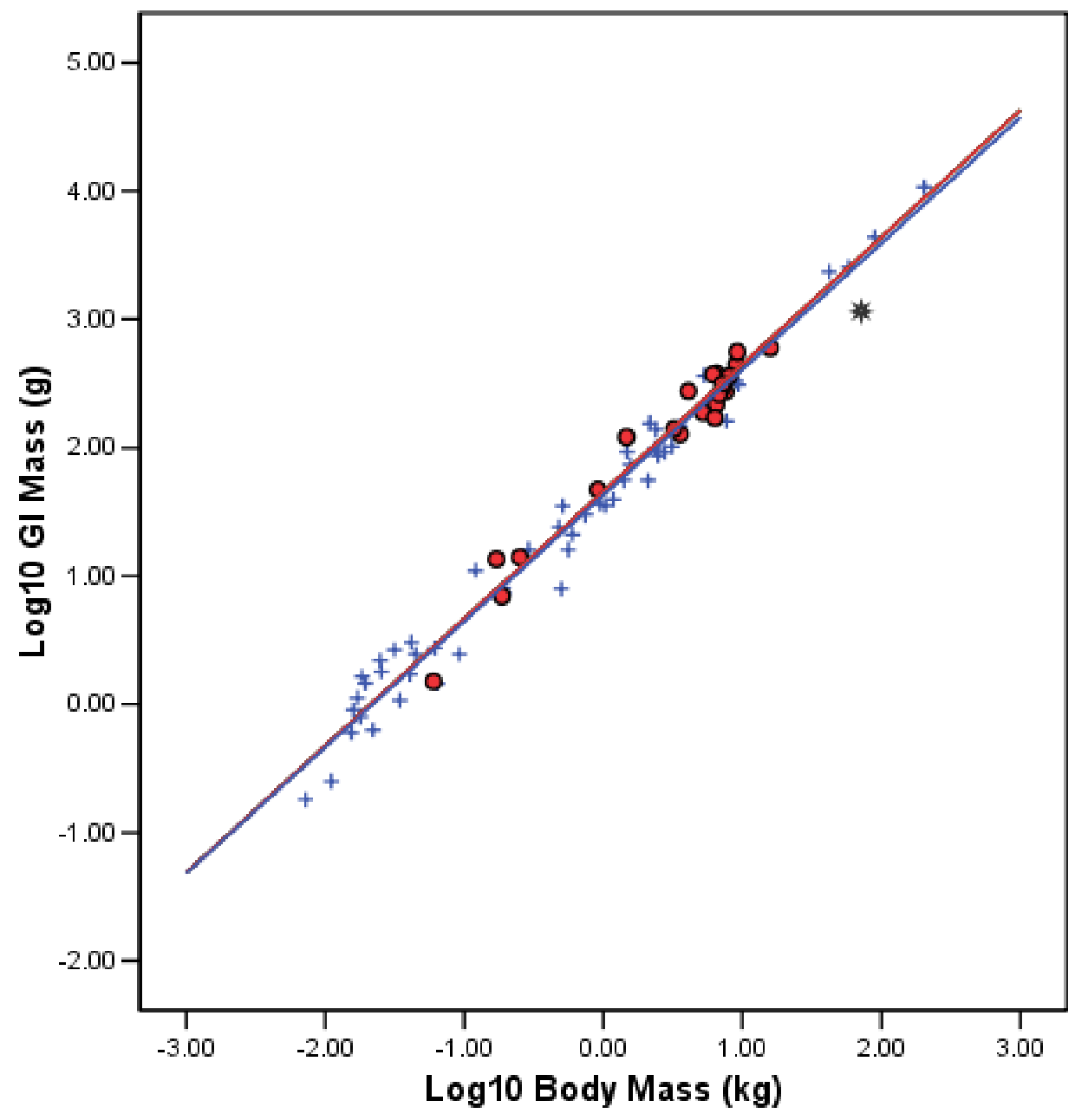

† Primates

Figure 1. Log-log plot of total gastrointestinal mass $(\mathrm{g})$ vs. body mass $(\mathrm{kg})$ in primates and non-primate mammals. For additional information on sample, see Snodgrass et al., in prep. 


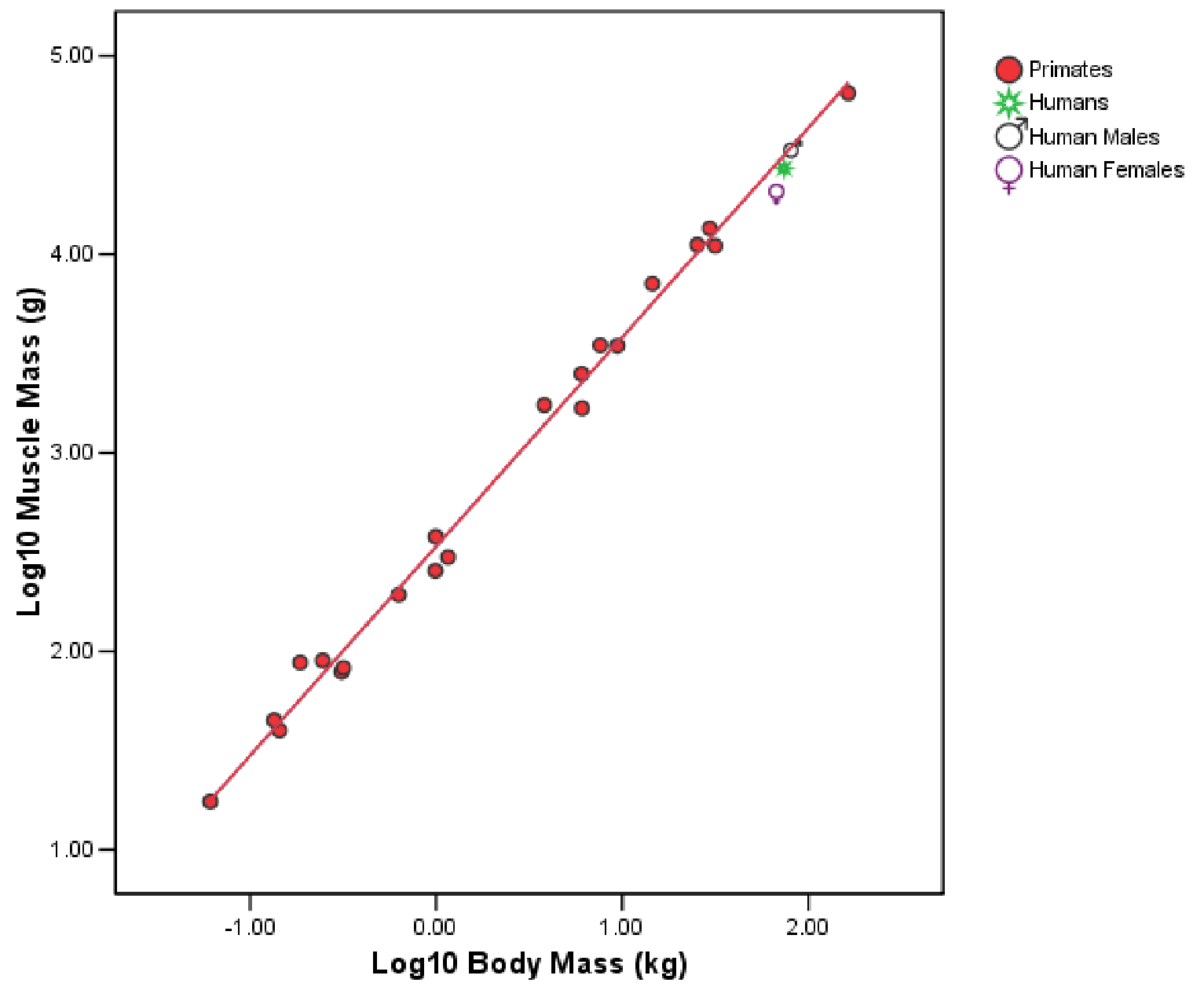

Figure 2. Log-log plot of muscle mass (g) vs. body mass ( $\mathrm{kg}$ ) for primates. Humans fall below the primate ( standardized residual $=-0.65$ ), indicating they are undermuscled compared to other primates. For additional information on the sample, see Muchlinski et al., in prep. 